\title{
Political determinants of social expenditures in Greece: an empirical analysis
}

\author{
EBRU CANIKALP, Res. Asst.* \\ ILTER UNLUKAPLAN, Assoc. Prof.*
}

Preliminary communication**

JEL: C31, D7, H53, I3

doi: $10.3326 /$ pse/41.3.5

\footnotetext{
* Revised version of the paper presented at ICIB 2017, held in Thessaloniki on May 19-21 2017. This study was funded by Cukurova University Scientific Research Projects Coordination Unit (SBA-2017-8847). We would like to thank to the two anonymous reviewers for their helpful suggestions and comments.

${ }^{* *}$ Received: June 28, 2017

Accepted: July 28, 2017
}

\section{Ebru CANIKALP}

Cukurova University, Faculty of Economics and Administrative Sciences, Department of Public Finance, 01330 Balcali, Saricam, Adana, Turkey

e-mail: ecanikalp@cu.edu.tr

ORCiD: 0000-0001-9071-4565

Ilter UNLUKAPLAN

Cukurova University, Faculty of Economics and Administrative Sciences, Department of Public Finance, 01330 Balcali, Saricam, Adana, Turkey

e-mail: ikaplan@cu.edu.tr

ORCiD: 0000-0002-5420-3642 


\section{Abstract}

$A$ view prominently expounded is that the interaction between the composition and the volume of public expenditures is directly affected by political, institutional, psephological and ideological indicators. A crucial component of public expenditures, social expenditures play an important role in the economy as they directly and indirectly affect the distribution of income and wealth. Social expenditures aim at reallocating income and wealth unequal distribution. These expenditures comprise cash benefits, direct in-kind provision of goods and services, and tax breaks with social purposes.

The aim of this study is to determine the relationship between political structure, i.e. government fragmentation, ideological composition, elections and so on, and the social expenditures in Greece. Employing data from the Comparative Political Dataset (CPDS) and the OECD Social Expenditure Database (SOCX), a time series analysis was conducted for Greece for the 1980-2014 period. The findings of the study indicate that voter turnout, spending on the elderly population and the number of government changes have positive and statistically significant effects on social expenditures in Greece while debt stock and cabinet composition have negative effects.

Keywords: social expenditures, political indicators, time series analyses

\section{INTRODUCTION}

Until the Great Depression began in August 1929, the role and responsibility given to the public sector by the fiscal traditionalist view was rather limited. This approach, which holds the duties, powers and responsibilities of the public sector in a narrow framework, rejected the concept of the "welfare state" in particular and did not consider the role of public policy aiming to equalise the distribution of income and wealth as a primary function. However, social expenditures became prominent as the Keynesian view dominated economic theory, stating that public sector expenditures on social welfare in different countries of the world are efficient instruments to achieve a fair distribution of income and wealth. With the general acceptance of this viewpoint, social expenditures were perceived as they indisputably are, as the main task of the public sector. The fact that these expenditures increased considerably in the 1960 s tended to increase the importance of the concept of "welfare state". Welfare states devote resources to education, healthcare and social protection, transfers to low-income groups being particularly prominent in this context.

The size and composition of social spending is influenced by many financial, economic, social and political variables. Numerous theoretical and applied studies indicate that the size and composition of social expenditures are influenced by many fiscal, economic, social and political variables. This study focuses on the political determinants of social expenditures in Greece for the 1980-2014 period. The first part of the study focuses on social expenditures and their historical devel- 
opment, and the second part on the political determinants of social expenditures. In the next section, the structure and development of social expenditures in Greece are examined. In the empirical part of the study, time series analysis aims at showing the effects of the indicators determining the political structure on the volume of social expenditures in Greece for the period of 1980-2014.

\section{SOCIAL EXPENDITURES AND THEIR HISTORICAL DEVELOPMENT}

In about 1930, some countries began to support a significant increase in social expenditures, such as unemployment benefits, pensions, health spending, and education spending, which influenced public welfare; other countries pursued policies with a minimum of social spending aimed at supporting a redistribution of income (educational spending excepted). The reason for this opposition can be attributed to the relatively different quantitative histories of countries and their political economies (Lindert, 1994; 1996).

During the $19^{\text {th }}$ century and the First World War, the share of tax revenue in the national income was around $10 \%$. With this limited budgetary revenue, the states fulfilled their primary tasks, while the volume of public services such as education and health was restricted. Political constraints can explain the low social spending in this century (Lindert, 2004:22). Regarding the political process in this period, the regulation of some restrictions in Europe in the late $19^{\text {th }}$ century was observed, provided that the right to vote and the conduct of policies for social spending and increasingky redistributive income was limited to landowners and income-earning males.

After the Great Depression of 1929, in many countries the share of tax revenue in national income increased and "the return of the state" occurred. The social functions undertaken by the state brought the concept of welfare state into the literature and the importance of social expenditures began to be discussed (Piketty, 2015:514-516). In this process, with the assumption that all adult citizens had an equal and single voice in the political decision-making process, the pursuit the franchise and equal citizenship in the process of political decision-making enabled universalization of the right to vote and transmission of social demands to parliaments in the $20^{\text {th }}$ century.

The intervention area of the welfare state is defined by Cochrane and Clarke (1993) as social security and social services. Briggs (1961), on the other hand, refers to a more comprehensive definition and states that the government must act in three ways in this manner. The areas of intervention of the welfare state are the provision of social services, meeting social needs and ensuring minimum living standards for the family and the individual. Mishra (1999) defines the welfare state as a middle way between socialism and capitalism. Esping-Andersen (1990) defines the welfare state, in a broader definition, as a set of institutional arrangements and rules that shape current social policy decisions, spending patterns, solutions and demand structures of citizens. Within the framework of these definitions, 
it is possible to say that this kind of view of the nature of the welfare state has widened the scope of the tasks with which government is charged and that governments have had to fund an increase in social spending.

In the third quarter of the $20^{\text {th }}$ century, there was a turning point in countries in which the tendency towards solidarity decreased and neo-liberal policies came into prominence. In this period, the world was faced with many problems such as inflation in the USA, the Vietnam War, oil crises and stagflation crisis. As the cause of these problems was not the welfare state policy pursued, the solution should not have been criticism of the welfare state (Stiglitz, 2015). Despite the perception that developments, international competition, supply-side policies and the more rapidly globalizing world were treated as the end of the welfare state by some researchers (Özdemir, 2007), with the World Bank's 1997 Report called "Changing State in the World", an effective understanding of the state was adopted once again and an understanding of the facilitator state was adopted (World Bank, 1997).

\section{LIMITS AND POLITICAL DETERMINANTS OF SOCIAL EXPENDITURES}

In the literature, Alesina and Perotti (1996) have been highly influential with their definition of "budgetary institutions" in studies examining the effects of political indicators and political structure on public finance. According to this definition, budgetary institutions are are all rules and regulations which are in control of the design, approval and implementation of the budget. These conditions led to the endogeneity of budgetary institutions. Budgetary institutions can change, especially if the fiscal performance is not at an expected level or if it is a function of different social/political/historical variables that affect elections and fiscal performance indicators among different budget agencies. Milesi-Ferretti (1996) aggregated studies on budgetary institutions in two main groups. Contributions in the first group focused on constitutionally balanced budgetary amendments, international agreements, convergence criteria such as the Maastricht Criteria, macroeconomic program criteria, and statutory upper limits on public debt while the studies in the second group focused on budgetary procedures, spending ministers representing the interests of a particular electoral district, the role of budgetary institutions, the effects of the privilege of different ministers, parliamentarians, pressure groups and public institutions. Von Hagen (1992) and Von Hagen and Harden (1995), claim that the performance of public finance is related to two factors: principal-agent and common pool problems. According to the authors, these are the factors that directly result in increases in public expenditures.

To examine the political reflection of the concept of welfare, Spicker (2003) examines the most rough expression of the concepts of "left" and "right" in two separate perspectives. While the left wing supports the welfare state, social spending and an active state, the right wing is individualist and adopts the residual welfare state conception (Özdemir, 2007). This political reflection, of course, also affects social expenditure policies. It is possible to say that the level of social expenditure policies change from country to country. There are many historical, fiscal, economic and 
political reasons behind this dispute. In this study, the change discussed and analysed above in the context of political science, is studied in the perspective of political determinants. These political determinants can be aggregated as political fractionalization, party ideology and electoral systems and periods.

\subsection{POLITICAL FRACTIONALIZATION}

Political fractionalization, one of the political determinants of public expenditures, is associated with the number of parties that have representatives in parliament, the number of ministers in the cabinet and the ministers' party and membership status.

It is possible to explain political fractionalization by the "common pool problem". In a coalition consisting of $N$ politicians, a politician will try to maximize the interests of his constituency (Le Maux et al., 2011), which will lead to an increase in public expenditures. In a coalition consisting of $N$ politicans, different fractions indicate different numbers of budgetary demands and different interests.

Geys (2004) deals political fractionalization in two aspects, namely, voter and decision-maker perspective. Political fractionalization corresponds to the number of alternatives proposed by the politicians, or in other words the number of parties competing in the election. The voter can choose between options $p 1$ and $p N$. For decision-makers, political fragmentation corresponds to scattered political power (Alesina and Rosenthal, 1995) or to a coalition. A politician discusses and evaluates the demands placed between $p 1$ and $p N$ within the framework of public policies and applies a policy choice to the current problem by going to a common decision.

Weingast, Kenneth and Christopher (1981) emphasize that the fractionalization process in the decision-making process has a significant impact on public expenditure. Since there are different interests from a geographical point of view, it is difficult to choose the most suitable project from the political point of view, which emphasizes the importance of the institutions and rules in the process.

According to Ricciuti (2004), political fractionalization is based on the fiscal policies of the 1980s. The financing of public activities and the scope of fiscal policy instruments are shaped by political actors. The lack of time optimization between public deficits, the amount of debt, the collection of taxes and the making of expenditures in the 1980s caused social welfare costs. From this point of view, the concept of political fractionalization, which partially regulates fiscal policy, has begun to be take the place in discussions of the benevolent state that tries to increase social welfare. Ricciuti (2004) categorises political fragmentations in terms of the number of fragmentations, institutional fragmentation and temporal fragmentation.

Alesina and Drazen (1991) argue that instability may arise in the fiscal policies observed during coalition periods. They state that the lower the degree of political 
integration, or, in other words, the greater the political fractionalization, the greater the public expenditure, and therefore the likelihood of a budget deficit arising.

Lijphart $(1984,1999)$ concludes that there is a relationship between political fractionalization and tax policies, while coalition governments follow a more optimistic government policy. In support of this view, there are also studies that have found that bipartite party coalitions have higher public expenditure than singleparty governments (Perotti and Kontopoulos, 2002).

\subsection{PARTY IDEOLOGY}

The relative strengths and ideological differences of the parties place importance on the share of the budget allocated for social welfare policies in the national income. It is not only the power of government, but also the ideology of parties, the number of seats in the assembly, the power of the opposition and the weight of the coalition of the parties and the weight of the parliaments that affect social expenditures, thereby affecting welfare (Hicks and Swank, 1992:668).

The concepts of "right" and "left", which has been used to express ideological divergence for 200 years, are used to indicate the contrast of thought and actions of political parties (Bobbio, 1996). According to Cameron (1985), the concept of ideology is based on the 1789 French Revolution. The division of the parliament, which is frequently discussed in the political science literature, into a left wing and a right wing, influenced the session of the French parliament.

From an economic point of view, the concepts of left and right wing are correlated with the need for state intervention and the free market, respectively. The left wing focuses on low income groups and the concept of labor, preferring income redistribution policies, while those on the right side argue that redistribution of income policies product a substitution effect, therefore these expenditures should be limited (Budge, Robertson and Hearl, 1987).

Cameron (1985) reached the conclusion that with the increase in the number of delegates on the left-hand side in the assembly for the period of 1960-1975 and an increase was observed in gross domestic product and public expenditures. As a result, left wing had higher public expenditures than right-wing governments.

Rose (1984) opposed the view that it is the difference in party ideology that influences spending policies. The study of Rose (1984) indicates that there is a very small difference between the parties in terms of the volume of public expenditures and that the effect of ideology on public expenditure is insignificant. He supported this viewpoint with the increase in public spending during the periods each government was in power in England from 1957 to 1982, the rate of increase during the Labor Party periods being less than in periods in which the Conservative Party was in power. According to the author, party which win election can change the cabinet but can not change the formal rules. Rose (1984) underlines the fact that 
spending commitments will put pressure on party groups and that public spending will not change significantly.

Alesina and Tabellini (1990) assessed a situation in which two different party ideologies or decision makers have different views on the total level of public spending rather than on the composition of government expenditures. While "conservative" policymakers prefer reducing public spending not to have budget deficit, liberal policy makers are following policies aimed at achieving a budget surplus. In addition, different experiences and political fractionalization of countries indicate that public expenditure influences the flexibility of the political decisionmaking process.

Hicks and Swank (1992), Hicks and Misra (1993) examined the effects of ideological differences on social spending. They pointed out that social spending increases during periods when left and center parties are in power; Solano (1983) has concluded that there is no link between social expenditures and ideological changes.

Kittel and Obinger (2002) employed cross-section regression analysis to discover the relationship between the long-term impact of political parties and institutional constraints. Their findings indicate that secular conservative parties supports social expenditures, while the positive impact of leftist parties is fragile and Christian democratic parties are conservative in social expenditures.

\subsection{ELECTORAL SYSTEMS AND PERIODS}

The effect of policies on the economy was first examined by Nordhaus (1975), who has introduced into the literature the concept of political business cycles. In his work, Nordhaus notes that the politician who wants to be elected again, or who has the desire to win the election and the vote-maximizing mentality, tends to favour higher public expenditure. Rogoff (1990) states that in the election periods, politicians invest in expenditure items that the voter can visually see, and aim to win the votes of the median voter. Undoubtedly, social spending is also an important expenditure component that affects voters' voting decisions.

In his study of the relationship between social welfare spending and election periods in the US between 1960-1978, Tufte (1978) points out that there is a significant increase in transfer payments such as old-age pensions, disability and insurance payments and social security expenditures during the election period. Hicks and Swank (1992) argue that the competition in the election period has strengthened the social welfare considerations. On the other hand, some part of the literature shows that the competition in the election period is not a factor that has much effect on social expenditures (Lago-Penas and Lago-Penas, 2009).

Electoral systems are divided into proportional and majority systems. In proportional electoral systems, parties are awarded seats in proportion to the votes they 
receive, while in the majority system, the party that receives the most votes has the largest number of parliamentary seats. Iverson and Sockice (2006) investigated the relationship between social spending patterns and electoral systems, and found that social spending is more prevalent in the proportional than in the majority election system. Jurado (2014) emphasizes that party systems have a positive influence on social spending; Jurado and Leon (2013) point out that in the majoritarian electoral system, politicians are more sensitive to citizens who demand social spending in narrow regions and that social spending in the majoritarian electoral system is higher than the relative election system.

\section{SOCIAL EXPENDITURES IN GREECE}

Greece's social modernization program which is "the Mediterranean welfare state" (Tinios, 2015) gained importance because its accession to the European Union in 1981. Within this period, an egalitarian policy for the redistribution of income was accepted, extending social insurance coverage, improving access to social services and eliminating regional inequalities. In the last thirty years, the level of social expenditure in Greece has increased rapidly, reaching a limit. Graph 1 compares social expenditures as a percentage of GDP in Greece and OECD countries for the 1980-2014 period.

\section{GraPh 1}

Social expenditures in Greece and OECD countries between 1980-2014

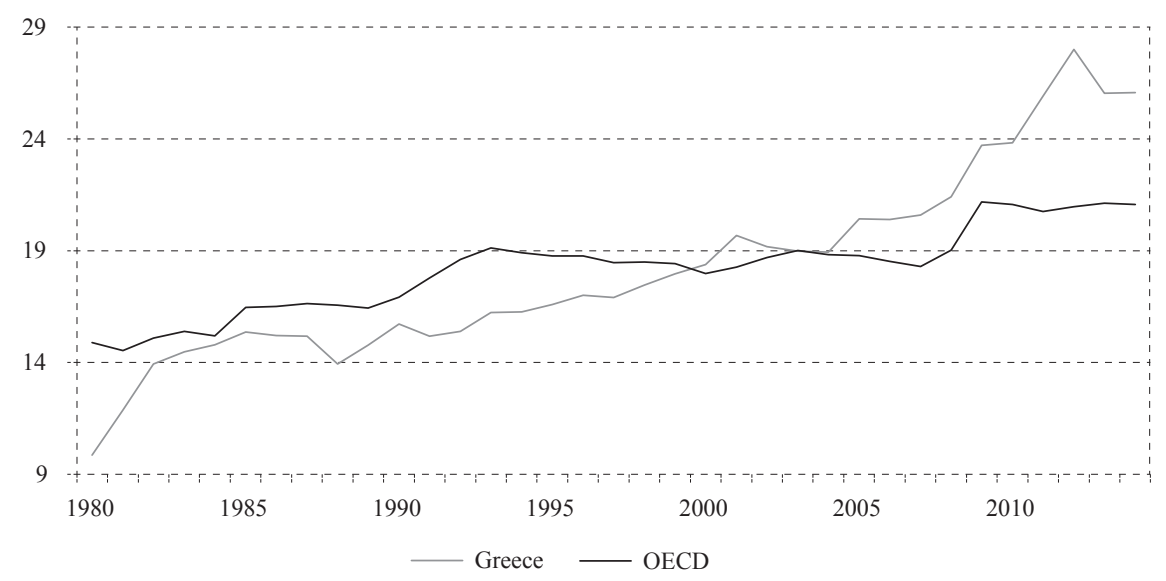

Source: OECD Social Expenditure Database (SOCX).

As indicated by graph 1, social expenditures in Greece in the 1980s were lower than the average of OECD countries. However, between 1980-1982, there was a significant increase in Greece and this rise continued in the 1982-1987 period. The major reason behind this increase was the health reform program in 1983. During the PASOK government (Pan Hellenic Socialist Party), the health system was revised and social security expenditures were raised (Sakellaridis, 2009). In the same period, an expansionary income policy was also implemented to reduce income inequality. 
From the graph 1 a decrease in social expenditure is observed in Greece in the 1985-1988 period. In this time interval, the PASOK government began to pursue a right wing policy in economy and aimed at reducing the budget deficit and inflation (Sakellaridis, 2009). These restrictive policies caused a reduction of the share of social spending in total government expenditures.

The 1989-1990 period was witness to political instability in Greece. In 1990 the New Democratic Party came to power and remained in power until 1993 (Sakellaridis, 2009). With neoliberal policies in most of the world in this period, privatization and liberalization policies were also experienced in Greece. These neoliberal policies affected social policy and there was a decrease social expenditure rate in 1990-1991.

The period between 1991-1997 included dramatic increase in social expenditures in Greece. This situation can be linked to social security expenditures. While in 1981 each person who had a job used social expenditure provided by the government, in 1990 anyone who had a job at home or was part time employee was also able to benefit from the social security network. In addition, in 1996, Law No. 2434 on "Policy Measures for Employment and Vocational Education and Training and Other Provisions" was enacted. It provided that the government make a payment each month for low income pensioners regardless of the age limit and elders who did not receive a salary (OECD, 2013). Due to the social security reform in 1996, in Law No. 2434, the population is included in the social security network increased, and this increase led to an increase in social expenditues.

As inferred from graph 1, the greatest rises in social expenditures can be observed after 2004. The most important reason for that was that Greek National Reform Programme (NRP) was signed by European Commission. That programme emphasized fiscal consolidation, public administration modernization, employment, education and increasing the importance of lifelong learning. Social policies gained in importance via that programme and the share of social expenditures in total expenditures were increased (Yfantopoulos, 2010).

In accordance with this report, the government published the Greek National Strategy Report on Pensions in 2005, the aim of which was to set out a rational and objective pensions reform. After this reform, measures to solve the problem of social security were taken and several banking sector funds were created. The main policies were an increase in the minimum pension age and the requirement for people to stay longer in active employment (OECD, 2013).

Greece reached the limit of its social expenditure with the 2008 crisis, and the number of funds in the social security system was reduced from 130 to 13 . These 13 funds still cover the majority of the population. Furthermore, the Manpower Employment Organisation (OAED), an independent institution as a part of Ministry of Labor, Social Security and Welfare, provides unemployment insurance and family benefit (OECD, 2013). 
While the poverty rate in the country in 2009 was $19.6 \%$, this ratio has risen to $36 \%$ by 2014 , with the economic recession and austerity measures (EUROSTAT, 2017). After the crisis, the unemployment rate in Greece tripled from $8.5 \%$ in 2007 to $26.7 \%$ in 2014 (EUROSTAT, 2017). The 2008 crisis and austerity policies led to an increase in the rate of poverty in the country and it has caused a significant rise in the number of people who are social assistance recipients.

The share of social expenditures was about 26\% of GDP in 2014 in Greece. While the share of pension and social security expenditures was $22 \%$ of GDP, the other expenditures remained at 4\% of GDP. The highest rate of pension and social security is a critical issue. The Greek pension system is a "pay as you go". In this system, current contributions collected from workers are for current pensioners. It is also based on pension funds. But in Greece this pension policy was not successfully implemented. Although some groups, who are subject to a lower retirement age, such as 42 or 50, and have low contribution rates, generous and high replacement rates were paid. In addition to this, the speed of population aging creates unequal redistribution and problems for the pension system (Tinios, 2016).

In the 2016 sustainable governance report, it is emphasized that the pension system in Greece is unsustainable. The reason for this is that there are many opportunities for early retirement and a large of citizens who pay low pension. In 2011 , fewer than $40 \%$ of Greeks who were 55 to 64 were still working and this is a disadvantage for the system. Furthermore, Greece has a high replacement rate. This represents that ratio of retirement pensions to contributions during work. While for workers with average earnings, the gross replacement rate averages 57\% in the 34 OECD countries, in Greece, the replacement rate was more than $95 \%$ in 2011 . Although, the normal pension age in Greece is 65 , the early retirement option and pension ages for women reduce the will to work. In Greece, both the "income effect" from a high level of pension wealth and the "substitution effect" from reductions in pension wealth from working until age 65 motivates people to leave working life (OECD, 2011).

Greece has had to cut pension payments, decrease family benefits and raise the retriment age due to the crisis, causing a decline in overall social expenditures.

\section{DATA, EMPIRICAL AND ANALYTICAL FRAMEWORK}

In the empirical part of the study, the effects of indicators determining the political structure of Greece on the volume of social expenditures will be investigated by the time series methods for the period between 1980 and 2014.

The study is based on 3 hypotheses.

1) Social expenditures increase in proportion to political fractionalization and the number of changes in the governments.

2) Ideological differences and changes in the opinion of the cabinet increase social expenditures.

3) An increase in the number of elections and voter turnout increase the social spending. 


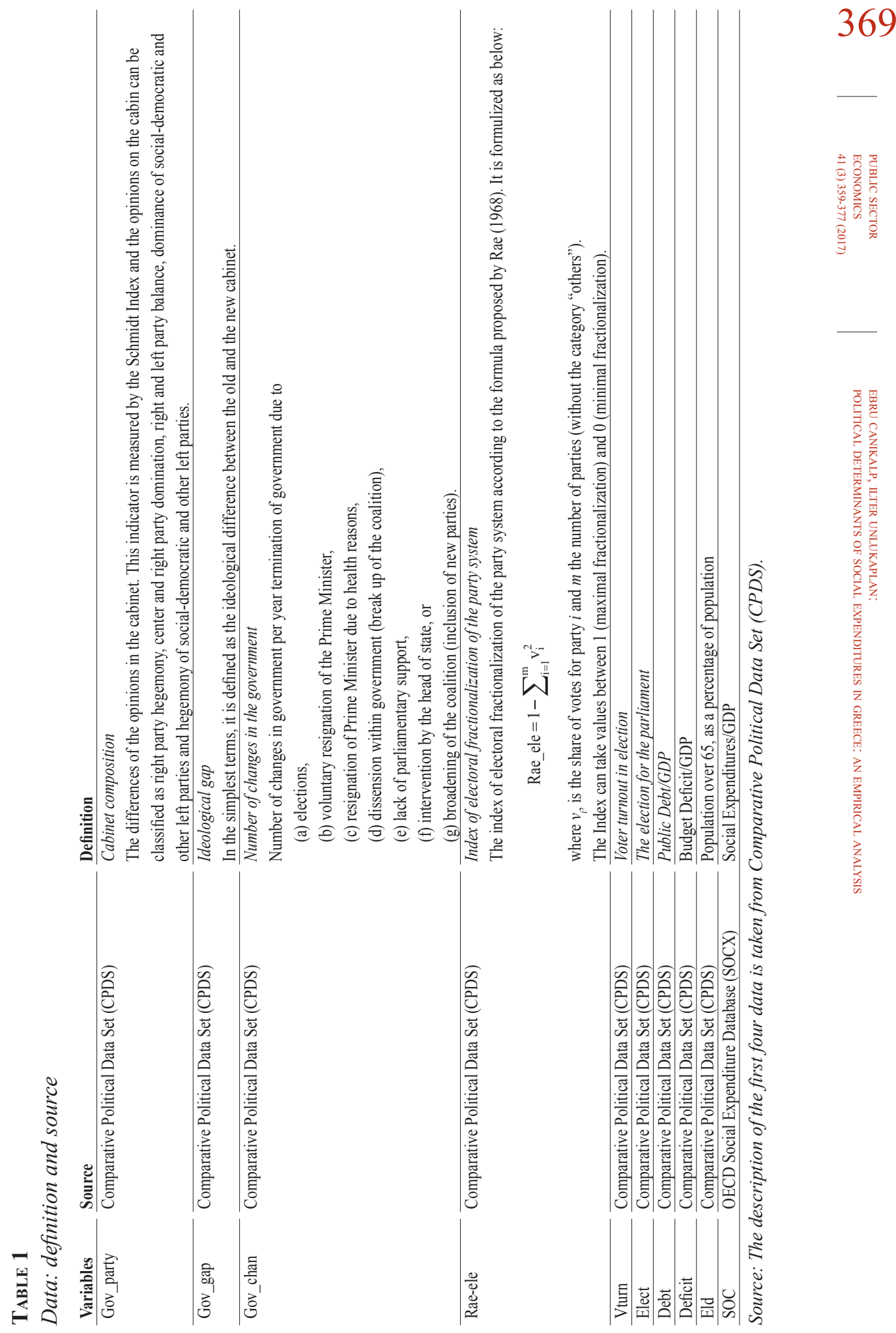


Political indicators used in the study were extracted from the Comparative Political Data Set (CPDS). The CPDS is a political and institutional dataset prepared annually by the researchers of Bern University since 1960. Although the data for Greece began in 1960 in the CPDS, the starting year for the study was based on 1980. The reason for this is the lack of access to the social expenditure data for Greece before 1980.

The variables, definitions and data sources to be used in the time series analysis aiming to specify the relation between the social expenditures and the political indicators are given in table 1 .

As inferred from table 1, Social Expenditures/GDP (SOC) was taken from OECD Social Expenditure Dataset while Cabinet Composition (Gov_party), Ideological Gap(Gov_gap), Number of Changes in the Government (Gov_chan), Index of electoral fractionalization of the party system(Rae-ele), Voter Turnout(Vturn) Election (Elect), Public Debt/GDP(Debt), Population over 65, as a percentage of population (Eld) were extracted from the Comparative Political Dataset (CPDS).

Time series analysis was conducted to show to what extent social expenditures were affected by political indicators in Greece for the 1980-2014 period. The analysis was conducted in EViews 9. We first tested whether the series have unit root in the empirical part of our work by employing the augmented Dickey Fuller test (ADF) (Dickey and Fuller, 1979; Dickey and Fuller, 1981). Three ADF models (the first with trend and intercept; the second with intercept and the third without trend and intercept) will be tested. According to the results from these tests, we will check whether the series have significant trends or intercepts.

TABle 2

ADF test results

\begin{tabular}{|c|c|c|c|}
\hline Variable & Model & $\mathbf{t}$ & Decision \\
\hline & 1 & -4.654 & \multirow{3}{*}{$\mathrm{I}(0)$} \\
\hline \multirow[t]{2}{*}{ s.g. } & 2 & . & \\
\hline & 3 & . & \\
\hline \multirow{3}{*}{ rae_ele } & 1 & -2.514 & \multirow{3}{*}{$\mathrm{I}(0)$} \\
\hline & 2 & . & \\
\hline & 3 &. & \\
\hline \multirow{3}{*}{ lnvturn } & 1 & -4.827 & \multirow{3}{*}{$\mathrm{I}(0)$} \\
\hline & 2 & . & \\
\hline & 3 & . & \\
\hline \multirow{3}{*}{ lneld } & 1 & -3.081 & \multirow{3}{*}{$\mathrm{I}(0)$} \\
\hline & 2 & . & \\
\hline & 3 &. & \\
\hline \multirow{3}{*}{ lndebt } & 1 & -2.680 & \multirow{3}{*}{$\mathrm{I}(0)$} \\
\hline & 2 & -3.504 & \\
\hline & 3 & . & \\
\hline \multirow{3}{*}{ deficit } & 1 & -3.112 & \multirow{3}{*}{$\mathrm{I}(0)$} \\
\hline & 2 & -3.226 & \\
\hline & 3 & . & \\
\hline
\end{tabular}


Since the $s o c$ variable contains a deterministic trend, the difference extraction process is applied to eliminate the trend. $s \_g$ is denoted as the new derived variable. For the $1^{\text {st }}, 2^{\text {nd }}$ and $3^{\text {rd }}$ models, the critical values at $5 \%$ significance level are $-3.56,-2.96$ and -1.95 , respectively. As the lneld and rae_ele variables contain a significant deterministic trend under the unit root hypothesis, the test statistics obtained are compared with the critical values of $t$ rather than the ADF critical values. In this case the unit root for both variables can be rejected. All variables are stationary at level (i.e., they are all $\mathrm{I}(0))^{1}$.

The regression equation to be estimated is given below in equation 1:

$$
\begin{aligned}
S \_G= & \beta_{0}+\beta_{1} R A E \_E L E+\beta_{2} L N V T U R N+\beta_{3} L N E L D+\beta_{4} L N D E B T+ \\
& \beta_{5} G O V \_P A R T Y+\beta_{6} G O V \_G A P+\beta_{7} G O V \_C H A N+\beta_{8} E L E C T+ \\
& \beta_{9} D E F I C I T+\epsilon
\end{aligned}
$$

The model estimated by the least squares method, standard linear regression procedure, is as follows.

\section{TABLE 3}

\begin{tabular}{|c|c|c|c|c|}
\hline \multicolumn{5}{|c|}{ Method: least squares } \\
\hline Variable & Coefficient & Std. error & t-statistic & Prob. \\
\hline RAE_ELE & -2.4359 & 5.7531 & -0.4234 & 0.6761 \\
\hline LNVTURN & 6.0825 & 3.3630 & -1.8086 & $0.0842 *$ \\
\hline LNELD & 6.1479 & 2.0586 & 2.9864 & $0.0068^{* *}$ \\
\hline LNDEBT & -1.9069 & 0.5424 & -3.5159 & $0.0019 * *$ \\
\hline GOV_PARTY & -0.1823 & 0.0962 & -1.8952 & $0.0713^{*}$ \\
\hline GOV_GAP & 0.1794 & 0.1169 & 1.5347 & 0.1391 \\
\hline GOV_CHAN & 0.5749 & 0.3343 & 1.7196 & $0.0995 *$ \\
\hline ELECT & -0.3704 & 0.4958 & -0.7471 & 0.4629 \\
\hline DEFICIT & -0.0576 & 0.0616 & -0.9359 & 0.3595 \\
\hline $\mathrm{C}$ & 20.3649 & 16.0078 & 1.2722 & 0.2166 \\
\hline R-squared & 0.5878 & \multicolumn{2}{|c|}{ Mean dependent var } & 0.5656 \\
\hline Adjusted R-squared & 0.4191 & \multicolumn{2}{|c|}{ S.D. dependent var } & 0.8601 \\
\hline S.E. of regression & 0.6555 & \multicolumn{2}{|c|}{ Akaike info criterion } & 2.2435 \\
\hline Sum squared resid & 9.4534 & \multicolumn{2}{|c|}{ Schwarz criterion } & 2.7016 \\
\hline Log likelihood & -25.8962 & \multicolumn{2}{|c|}{ Hannan-Quinn criter. } & 2.3953 \\
\hline F-statistic & 3.4853 & \multicolumn{2}{|c|}{ Durbin-Watson stat } & 2.3651 \\
\hline Prob(F-statistic) & 0.0081 & & & \\
\hline
\end{tabular}

OLS test results

Dependent variable: S_G

In the above model, the lneld and lndebt variables are statistically significant at the $5 \%$ significance level. The variables lnvturn and gov_party are statistically sig-

\footnotetext{
${ }^{1}$ lneld and rae ele test results for the significance of the trend are 8.068 and 7.074 respectively. The critical value at $5 \%$ for this test is 5.18 . According to this results, these two series have deterministic trend. For this reason their t-statistics obtained from the ADF test will follow normal distribution for the first ADF model and therefore we accepted these series are $\mathrm{I}(0)$.
} 
nificant at the level of 10 percent significance. The results of the analysis indicate that voter turnout, spending on the elderly population and the number of government changes, a proxy for political instability, have positive and statistically significant effects on social expenditures while debt stock and cabinet composition have negative effects. However, the negative effects of the index of electoral fractionalization of the party system, elections, budget deficit and the positive effects of ideological gap on the level on the social expenditures was not found to be statistically significant.

\section{CONCLUDING REMARKS}

OECD (2017) defines social expenditure as follows: Social expenditure is the provision by public (and private) institutions of benefits to, and financial contributions targeted at, households and individuals in order to provide support during circumstances which adversely affect their welfare, provided that the provision of the benefits and financial contributions constitutes neither a direct payment for a particular good or service nor an individual contract or transfer. Undoubtedly, this multi-dimensioned concepts is greatly influenced by political indicators.

Three hypotheses have been tested by time series techniques in this study, which examined the extent to which social expenditures were influenced by political indicators in Greece for the period 1980-2014.

The first hypothesis in the study was partially confirmed. In this context, the number of government changes, a proxy for political instability, has positive and statistically significant effects on social expenditures. This result confirms theoretical expectations and the results of previous studies. For all that, the negative but statistically insignificant effects of the index of electoral fractionalization of the party system were observed in Greece. In our opinion, this insignificant relation arises from the lack of any relationship between the ideology of the governments and the policies conducted in Greece. One should keep in mind that the PASOK government in the 1980s pursued both and left and right wing policies. However, in 2012, Prime Minister George Papandreou from a left wing party, implemented an austerity policy, because of the current situation in the country and the decisions taken by the EU Commission. Also, SYRIZA, which came to power in 2015, had to compromise its ideological stance for Greece to resolve economic problems.

The second hypothesis was not confirmed in our study. Our theoretical expectation was the positive relationship between social expenditures and ideological differences and changes in the opinion of the cabinet. The results of the analysis verify the positive effects of ideological gap on the level on the social expenditures but this relationship was not found to be statistically significant. On the other hand, in contrast to theoretical expectations, cabinet composition has negative and statistically significant negative effects on the level of social expenditures in Greece. The main reason why this hypothesis is not confirmed can be attributed 
to Greece's understanding of the state. Esping-Andersen (1990), for instance, classifies Greece as a social welfare state, providing social and economic services for welfare maximization purposes. With this act, it can be stated that although there were changes in the cabinet, social expenditures increased due to the settled perception of the state in Greece.

In relation to the third hypothesis, while the positive impact of voter turnout on social spending was clearly observed, no findings were found to indicate the effect of the elections on the volume of social expenditures. This evidence validates the hypothesis that during the election times, governments in Greece do not employ social expenditures as a policy instrument.

Regarding control variables, not surprisingly, a positive and robust relationship was observed between the population over 65 as a percentage of total population. This finding was in accord with our expectation, as early retirement opportunities and comprehensive social security expenditures were prominent in the specified period. While debt stock and budget deficit have negative effects, only the former has a statistically significant relationship.

According to OECD Report (OECD, 2013), Greece as a social welfare state follows complex, fragmentary welfare system without a clear strategy. Despite reforms made in the system, the desired success have not been attained. This situation is an indicator that the system needs to be revised. Reforms under the Ministry of Labour, Social Security and Welfare should continue and provide a coherent strategy for efficient and effective social welfare policy and public governance. These results and observations confirm that Greece has a peculiar political structure and social spending system.

\section{Disclosure statement}

No potential conflict of interest was reported by the authors.

\section{Funding}

This article that is production of project, is revised version of the paper presented at ICIB 2017, held in Thessaloniki on May 19-21 2017. The project name is "Sosyal Harcamaların Politik Belirleyicileri: Seçilmiş OECD Ülkeleri İçin Ampirik Analiz", it has been funded by Cukurova University - BAP (Scientific Research Projects). The project budget is 12000 TL and it will continue until February 2018. 


\section{REFERENCES}

1. Alesina, A. and Perotti, R., 1996. Budget Deficits and Budget Institutions. IMF Working Papers, No. 96/52.

2. Alesina, A. and Drazen, A., 1989. Why are Stabilizations Delayed? NBER Working Papers, No. 3053.

3. Alesina, A. and Rosenthal, H., 1995. Partisan politics, Divided Government and the Economy. Cambridge: Cambridge University Press. doi: 10.1017/ CBO9780511720512

4. Alesina, A. and Tabellini, G., 1990. A Positive Theory of Fiscal Deficits and Government Debt. Review of Economic Studies, 57(3), pp. 403-414. doi: $10.2307 / 2298021$

5. Armingeon, K. [et al.], 2016. Comparative Political Data Set 1960-2014. Bern: Institute of Political Science.

6. Bobbio, N. 1996. Left and Right: The Signifance of a Political Distinction. Chicago: The University of Chicago Press.

7. Briggs, A., 1961. The Welfare State in Historical Perspective. European Journal of Sociology, 2(2), pp. 221-258. doi: 10.1017/S0003975600000412

8. Budge, I., Robertson, D. and Hearl, D. (eds.), 1987. Ideology, strategy and party change: Spatial analysis of post-war election programmes in nineteen democracies. Cambridge: Cambridge University Press.

9. Cameron, D., 1978. The Expansion of the Public Economy: A Comparative Analysis. American Political Science Review, 72(4), pp. 1243-1261. doi: $10.2307 / 1954537$

10. Cochrane, A. and Clarke, J., 1993. Comparing Welfare States. London: Sage.

11. CPDS - Comparative Political Data Set, 2017. Available at: <http://www. cpds-data.org $>$.

12. Dickey, D. A. and Fuller, W. A., 1979. Distribution of the Estimators for Autoregressive Time Series with a Unit Root. Journal of the American Statistical Association, 74(366a), pp. 427-431. doi: 10.1080/01621459.1979.10482531

13. Dickey, D. A. and Fuller, W. A., 1981. Distribution of the Estimators for Autoregressive Time Series with a Unit Root. Econometrica, 49, pp. 1057-1072. doi: $10.2307 / 1912517$

14. Esping-Andersen, G., 1990. The Three Worlds of Welfare Capitalism. Cambridge: Polity Press.

15. EUROSTAT, 2017. Available at: <http://ec.europa.eu>.

16. Geys, B., 2004. Proportional Representation, Political Fragmentation and Political Decision-Making: an Economic Analysis. PhD. Dissertation. Brussel: Vrije Universiteit Brussel.

17. Hicks, A. and Misra, J., 1993. Political Resources and the Expansion of Welfare Effort. American Journal of Sociology, 99(1), pp. 668-710. doi: $10.1086 / 230320$

18. Hicks, A. M. and Swank, D. H., 1992. Politics, Institutions, and Welfare Spending in Industrialized Democracies, 1960-1982. American Political Science Review, 86 (3), pp. 658-674. doi: 10.2307/1964129 
19. Iversen, T. and David, S., 2006. Electoral Institutions and the Politics of Coalitions: Why Some Democracies Redistribute More than Others. American Political Science Review, 100 (2), pp. 165-181. doi: 10.1017/S0003055406062083

20. Jurado, I. and Leon, S., 2013. The Conditional Effect of Electoral Systems on Social Spending. British Journal of Political Science, 42 (4), pp. 855-877.

21. Jurado, I., 2014. Party System Nationalization and Social Spending. European Journal of Political Research, 53, pp. 288-307. doi: 10.1111/1475-6765.12035

22. Kittel, B. and Obinger, H., 2002. Political Parties, Institutions and the Dynamics of Social Expenditure in Times of Austerity. MPlfG Discussion Paper, No. $02 / 1$.

23. Lago-Penas, I. and Lago-Penas, S., 2009. Does the Nationalization of Party Systems Affect the Composition of Public Spending? Economics of Governance, 10(1), pp. 85-98. doi: 10.1007/s10101-008-0051-x

24. Le Maux, B., Rocaboy, Y. and Goodspeed, T., 2011. Political Fragmentation, Party Ideology and Public Expenditures. Public Choice, 147(1), pp. 43-67. doi: $10.1007 / \mathrm{s} 11127-010-9603-\mathrm{z}$

25. Lijphart, A. L., 1984. Democracies. Patterns of Majoritarian and Consensus Government in Twenty-One Countries. New Haven/London: Yale University Press.

26. Lijphart, A. L., 1999. Patterns of Democracy. Government Forms and Performance in Thirty-Six Countries. New Haven/London: Yale University Press.

27. Lindert, P. H., 1994. The Rise of Social Spending, 1880-1930. Explorations in Economic History, 31(1), pp. 1-37. doi: 10.1006/exeh.1994.1001

28. Lindert, P. H., 1996. What Limits Social Spending? Explorations in Economic History, 33(1), pp. 1-34. doi: 10.1006/exeh.1996.0001

29. Lindert, P. H., 2004. Growing Public Social Spending and Economic Growth since the Eighteenth Century. Cambridge: Cambridge University Press.

30. Milesi-Ferretti, G. M., 1996. Fiscal Rules and the Budget Process. IMF Working Papers, No. 96/60.

31. Mishra, R., 1999. Globalization and the Welfare State. London: Edward Elgar.

32. Nordhaus, W., 1975. The Political Business Cycle. Review of Economic Studies, 42, pp. 169-190. doi: 10.2307/2296528

33. OECD, 2011. OECD Pensions at a Glance 2011: Retirement-income Systems in OECD and G20 Countries. Paris: OECD. Available at: <http://www.oecd. org/statistics>.

34. OECD, 2013. Greece: Reform of Social Welfare Programmes. Paris: OECD.

35. OECD, 2017. Social Expenditure Database (SOCX). Paris: OECD. Available at: <http://www.oecd.org/social/expenditure.htm>.

36. Özdemir, S., 2007. Küreselleşme Sürecinde Refah Devleti. İTO, Yayın No. 2007-57.

37. Perotti, R. and Kontopoulos, Y., 2002. Fragmented fiscal policy. Journal of Public Economics, 86, pp.191-222. doi: 10.1016/S0047-2727(01)00146-3 
38. Piketty, T, 2015. Capital, Inequality and Justice: Reflections on Capital in the Twenty-First Century. PSE - Labex "OSE-Ouvrir la Science Economique" halshs-01207278, HAL.

39. Rae, D. W., 1968. A Note on the Fractionalization of Some European Party Systems. Comparative Political Studies, 1, pp. 413-418. doi: 10.1177/001041406800100305

40. Ricciuti, R., 2004. Political Fragmentation and Fiscal Outcomes. Public Choice, 118(3), pp. 365-388. doi: 10.1023/B:PUCH.0000019909.77676.85

41. Rogoff, K., 1990. Political Budget Cycles. American Economic Review, 80, pp. 1-16.

42. Rose, R., 1984. Do Parties Make a Difference? Chatham, N.J.: Chatham House. doi: 10.1007/978-1-349-17350-1

43. Sakellaridis, G. 2009. “An Empirical Investigation of Social Protection Expenditures on Economic Growth in Greece" in: Paper for the $4^{\text {th }}$ Hellenic Observatory PhD Symposium on Contemporary Greece, Hellenic Observatory. European Institute, LSE Hellenic Observatory, European Institute, 2526, June 2009.

44. SOCX - Social Expenditure Database Available at: <http://www.oecd.org/ social/expenditure.html>.

45. Solano, P. L., 1983. Institutional Explanation of Public Expenditure among High Income Democracies. Public Finance, 38, pp. 440-458.

46. Spicker, P., 2013. Social Administration, An introduction to Social Policy, Available at: $<$ http://spicker.uk/social-policy/socadmin.htm>.

47. Stiglitz, J., 2015. "The Welfare State in the Twenty First Century" in Welfare and Inequality, Joseph E. Stiglitz and Jose Antonio Ocampo (eds.), Initiative for Policy Dialogue at Columbia, to be published by New York: Columbia University Press.

48. Tinios, P., 2015. Report on the Greek pensions system: Towards a new social contract (Identification of shortcomings and propositions of solutions for the establishment of an improved, sustainable and economically-sound pension structure). Brussel: TFFG

49. Tinios, P., 2016. The Greek Pension Tragedy: A Case of Failure in Governance. Available at: <http://www.kas.de>.

50. Tufte, E. R., 1978. Political Control of the Economy. Princeton: Princeton University Press.

51. Von Hagen, J. and Harden, I., 1995. Budget Processes and Commitment to Fiscal Discipline. European Economic Review, 39, pp. 771-779. doi: 10.1016/0014-2921(94)00084-D

52. Von Hagen, J., 1992. Budgeting Procedures and Fiscal Performance in the European Communities. Center for German and European Studies Economic Papers, No. 96.

53. Weingast B. R., Kenneth A. S. and Christopher, J., 1981. The Political Economy of Benefits and Costs: A Neoclassical Approach to Distributive Politics. Journal of Political Economy, 89(4), pp. 642-664. doi: 10.1086/260997 
54. World Bank. 1997. The State in a Changing World, World Development Report. Washington: The World Bank.

55. Yfantopoulos, J. N., 2010. "The Welfare State in Greece" in A. J. Bacaloumis, ed. About Greece. General Secretariat of Communication, General Secretariat of Information, pp. 328-342. 